\title{
Environmental screening tools for assessment of infrastructure plans based on biodiversity preservation and global warming (PEIT, Spain)
}

\author{
Luis G. García-Montero ，Elena López ,Andrés Monzón ， Isabel Otero Pastor \\ Dept. Forest Engineering. E.TS. Ingenieros de Montes, Technical University of Madrid (UPM), Ciudad Universitaria s/n, Madrid 28040, Spain \\ TRANSyT, E.T.S. Ingenieros de Caminos, Technical University of Madrid (UPM). Avda. Profesor Aranguren s/n, Madrid 28040, Spain
}

Keywords:

Environinental screening

Strategic environmental assessment

Infrastructure planning

Landscape planning

\begin{abstract}
A B S T R A C T
Most Strategic Environmental Assessment (SEA) research has been concerned with SEA as a procedure, and there have been relatively few developments and tests of analytical methodologies. The first stage of the SEA is the 'screening', which is the process whereby a decision is taken on whether or not SEA is required for a particular programme or plan. The effectiveness of screening and SEA procedures will depend on how well the assessment fits into the planning from the early stages of the decision-making process. However, it is difficult to prepare the environmental screening for an infrastructure plan involving a whole country. To be useful, such methodologies must be fast and simple. We have developed two screening tools which would make it possible to estimate promptly the overall impact an infrastructure plan might have on biodiversity and global warming for a whole country, in order to generate planning alternatives, and to determine whether or not SEA is required for a particular infrastructure plan.
\end{abstract}

\section{Introduction}

The phenomenon of climate change is directly linked to energy consumption and to greenhouse gas (GHG) emissions. At the EU level, the transport sector is the primary driver of the growth in total energy consumption, which is likewise directly linked with total emissions (EEA, 2006a). Despite the considerable efforts devoted to environmental abatement policies, the high rate of increase in transport demand is outstripping the rate of improvement in environmental technology for transport (Stead, 2001). The result has been a significant increase in greenhouse gas (GHG) emissions from transport, which threatens Europe's progress towards its international commitments, such as the Kyoto targets (UNFCCC, 1997) and the proposals by the EU Council for further emission reductions for developed countries beyond the Kyoto Protocol period (2008-2012) (EC, 2005). The reduction of air pollution is also on the EU agenda, although energy-related emissions $\left(\mathrm{NO}_{x}, \mathrm{SO}_{2}\right.$, VOCs) from the transport sector have decreased steadily since 1990 (EEA, 2006b; López, 2007), largely due to the result of increasingly strict emissions standards for the different transport modes, and to fuel switching.
The loss of biodiversity and quality of the environment associated with new transport infrastructure are also concerns for transport policy at the strategic level (EEA, 2006b), as established by the principles of international environmental policy, whose aims are to 'conserve and improve the quality of the environment... based on the precautionary principle' (Articles 6 and 174 of the EU Treaty; Oñate et al., 2002); and which proposes the integration of conservation and sustainable use of biodiversity into the various plans and programmes' (Convention on Biological Diversity 1992, Rio Earth Summit). Treweek et al. (1998) indicate that infrastructure developments, when considered collectively, can be compatible with safeguarding important and protected wildlife habitats and their associated protected species. Norris and Farrar (2001). Brown (2003) and Schumaker et al. (2004) indicate that environmental quality is becoming recognized as a critical factor that should constrain land-use planning, and they also recommend that specialists should adopt approaches in which environmental quality information assists those involved in the development plans.

The Strategic Environmental Assessment (SEA) is one of the best allround tools for environmental protection, as it permits the concept of sustainability to be integrated into the planning process (Partidario, 2000; Alshuwaikhat, 2005; Chaker et al., 2006). However, the effectiveness of SEA depends on how well the assessment fits into the planning context. Specific procedural steps may improve its effectiveness, but explicit requirements to recognize SEA in decision-making are likely to be a key condition (Dalkmann et al., 2004; Hilden et al., 2004). SEA must therefore assess the effects on the environment from the early stages of the decision-making process in plans and development initiatives (Kessler and Van Dorp, 1998). The European Union recommends that the SEA should be done during the preparatory 
stages of a plan and prior to its adoption or to any legal procedures, with the aim of ensuring that SEA is taken into account in the planning process (European Directive 2001/42/EC).

These authors and European Directive indicate that the first stage of a SEA is the screening process. Screening is defined by the European Commission as 'the process by which a decision is taken on whether or not SEA is required for a particular programme or plan'. The European SEA Directive (EC, 2001) also specifies that screening should be used in the decision-making process to generate planning alternatives and to contribute to an improvement in the plan itself.

Screening research has made little progress in developing analytical methodologies to resolve technical problems and to incorporate new findings into the planning process. Von Seht (1999) and Thérivel (2002) point out that it has not been easy to arrive at a methodology for the SEA and screening models. Polichtchouk (1998) indicates that the complex and interdisciplinary nature of environmental problems requires the development of a new class of GIS (Geographic Information System), integrating mathematical models, databases and expert knowledge based on a conceptual model.

In light of the scarcity of literature exploring the practical implementation of environmental screening, our paper attempts to contribute to the growing body of knowledge on best practices for this tool. The general objective of the present study is therefore to develop a screening model which would make it possible to estimate promptly the overall impact a Spanish infrastructure plan might have on the environment for the whole Spanish territory $\left(500,000 \mathrm{~km}^{2}\right)$, and to integrate this screening into the SEA and decision-making processes. Based on this aim and on previous screening model studies (López, 2007; García-Montero et al., 2008, 2010), our proposal for the environmental screening of infrastructure plans is based on two screening tools for assessment of infrastructure impacts on biodiversity preservation and global warming.

\section{Methods}

2.1. The example of the infrastructure plan: Spanish transport infrastructure plan PEIT 2005-2012 guidelines

In December 2004, the Spanish Ministry of Public Works proposed a strategic infrastructure and transport plan known as the PEIT (Ministerio de Fomento, 2004). This document establishes that the priorities in the road transport system for the 2005-2012 period are centred around improving the conditions of service throughout the network with regard to safety and maintenance; streamlining the network by making changes in its structure; completing construction of the high-capacity routes; and the implementation of ITS (Intelligent Transport Systems). Two programmes of actions were set up for this purpose: intercity actions, and the definition of a new basic plan for the high-performance road network (the basic network, with about $15,000 \mathrm{~km}$ of infrastructures), which would improve Spain's current road structure. It also includes the termination of the high-capacity routes ( $>10,000$ vehicles/day), an action plan for long-distance routes, and a programme of construction of urban bypasses, among other projects.

The PEIT's objectives for the railway system are the transformation of this system into the central element of intercity transport services for both passengers and goods. This criterion will make it necessary to concentrate actions in the corridors in which there is greatest demand, and which have the greatest potential for improving accessibility to the whole of the Spanish territory. The actions will focus on the termination of the high-performance corridors and axes currently under construction, and the modernization of the conventional railway network in order to improve goods transportation services by rail, thereby facilitating the exchange between road and sea transport, and enabling interoperability with the French network, among other actions.

\subsection{A GIS model for biodiversity and environmental assessment}

\subsubsection{Step 1: Methodological basis}

We selected as the main valuation criteria the conservation of biodiversity and the preservation of the environment', and we used the methodology of Ramos (1979) and a GIS model proposed by Mancebo et al. (2005) and García-Montero et al. (2010) (LATINO model). These methodologies are based on models which compare the territorial units in relation to each other, based on the attributes or natural variables in each of them.

We looked for biodiversity and environment evaluation criteria based on existing environmental information on a national scale, and used this to draw up the GIS model for biodiversity and environmental assessment in Spain, based on five previous digital maps on a national scale (Table 1). These five maps allowed us to generate, either directly or by deduction, a set of 12 environmental qualities that represented 12 raster layers (Table 1 ). We considered that with these 12 variables it was possible to obtain a basic GIS model for biodiversity and environmental assessment which could be applied rapidly and effectively in the screening of a Spanish infrastructure plan. However. this GIS assessment model is an open system that allows continuous incorporation of new scores.

The GIS software, maps, raster operations and cartographic formats have been described by García-Montero et al. (2008). The datum and projection was selected according to Eurogeographics' recommendations (EEA, 1999; Geodäsie Eurogeographics EUREF, 2006). The precision threshold was established at $100 \mathrm{~m}$ RMS (equivalent to a scale of $1: 500,000)$

The vector modulus was selected as the method for integrating the different evaluations with numerical vectors. Tran et al. (2006) propose the vector modulus as a useful synthetic value for integrated environmental assessments. Ramos (1979), Martinez-Falero and González (1995), MMA (2000), Mancebo et al. (2005) and García-Montero et al.

Table 1

Twelve environmental variables were used in the GIS model for the assessment of biodiversity in spain (Mancebo et al., 2005; Garcia-Montero et al., 2008).

\begin{tabular}{|c|c|c|}
\hline $\begin{array}{l}\text { Environmental variable } \\
\text { GIS layers }\end{array}$ & $\begin{array}{l}\text { Digital maps on a } \\
\text { national scale }\end{array}$ & $\begin{array}{l}\text { Method for obtaining the } \\
\text { variables and cartographic } \\
\text { layers }\end{array}$ \\
\hline $\begin{array}{l}\text { Biodiversity quality and } \\
\text { naturalness associated } \\
\text { to the map units }\end{array}$ & $\begin{array}{l}\text { Coline Land Cover } \\
1990 \text { (EEA, 2003) }\end{array}$ & Panel of experts \\
\hline Singularity of the map units & & $\begin{array}{l}\text { Objective classification } \\
\text { calculated with SIG }\end{array}$ \\
\hline Naturalness of the map units & $\begin{array}{l}\text { European Habitats } \\
\text { map (DGCN, 2004a) }\end{array}$ & $\begin{array}{l}\text { Valuation by the experts } \\
\text { who generated the } \\
\text { oliginal map }\end{array}$ \\
\hline Singularity of the map units & & $\begin{array}{l}\text { Objective classification } \\
\text { calculated with SIG }\end{array}$ \\
\hline \multicolumn{3}{|l|}{ Habitat sizes of the map units } \\
\hline $\begin{array}{l}\text { Biodiversity quality and } \\
\text { naturalness associated } \\
\text { to the map units }\end{array}$ & $\begin{array}{l}\text { Spanish Landscape } \\
\text { map (MMA, 2004) }\end{array}$ & Panel of experts \\
\hline Singularity of the map units & & $\begin{array}{l}\text { Objective classification } \\
\text { calculated with SIG }\end{array}$ \\
\hline $\begin{array}{l}\text { Biodiversity quality and } \\
\text { naturalness associated } \\
\text { to the map units }\end{array}$ & Soil map (FAO, 2000) & Panel of experts \\
\hline Singularity of the map units & & $\begin{array}{l}\text { Objective classification } \\
\text { calculated with SIG }\end{array}$ \\
\hline Size of the forest units & $\begin{array}{l}\text { Spanish Forestry } \\
\text { Vegetation map } \\
\text { (DGCN, 2004b) }\end{array}$ & \\
\hline Total vegetation cover $(\%)$ & $\begin{array}{l}\text { Spanish Folestry } \\
\text { Vegetation and } \\
\text { Conine L.C. maps }\end{array}$ & \\
\hline Total forest cover (\%) & & \\
\hline
\end{tabular}

This GIS assessment model is an open system that allows the continuous incorporation of new scores. 
$(2008,2010)$ also propose the use of the vector modulus in environmental assessment for practical operating reasons. All the normalized variables used as components of the vectors vary between 0 and 1 , so to calculate each vector modulus, the origin of the coordinates was taken to be $\left\{x_{1}, \ldots\right.$. $\left.x_{n 1}\right)$ with $x_{i}=0(i=1 \ldots n)$.

In practice, it is difficult to prepare the screening of an infrastructure plan in a country as large and as diverse as Spain. Therefore, in our study we have applied the principle proposed by Ramos (1979) and Otero et al. (1999), who recommend that environmental assessment should focus on the impacts which a priori are seen to be most important. The common premise governing these procedures should be 'to devote the greatest possible effort to the most significant problems', and to apply maximum protection to the areas with the greatest biodiversity and environment quality.

2.2.2. Step 2: Valuation of variables by means of rapid consultations with paneis of experts

We consulted a panel of experts in order to obtain a set of four biodiversity and environmental valuation qualities to represent four raster layers (Table 1), according to the following procedures:

I. The biodiversity and naturalness associated to the units in the Corine Land Cover 1990 map (EEA, 2003) was based on the hierarchical classifications proposed by the Corine Project, and interpreted by four experts in vegetation and land-use at the School of Forestry in Madrid.

II. A map of naturalness of the units in the European Habitats map (DGCN, 2004a) was generated by obtaining a raster layer from an original vector map using a field containing a naturalness value ( 1 to 3 ) for each polygon on the map. These naturalness values were previously assigned by the experts who participated in the original vector map of the European Habitat Project.

III. The biodiversity and naturalness associated to the units in the Spanish Landscape map (MMA, 2004) were assessed using the legend, and interpreted by four experts at the School of Forestry in Madrid, based on the previous landscape research experience of this group (Otero Pastor et al., 2007).

IV. The biodiversity and naturalness associated to the units in the Soil map (FAO, 2000) was assessed using the legend, and then evaluating as a whole the productive capacity, biodiversity, naturalness and uniqueness of the soils in Spain. This was done following the FAO's hierarchical classifications of soil taxonomy, and interpreted by a panel of five experts from the Soil Sciences Department at the Complutense University in Madrid.

2.2.3. Step 3: Objective assessment of the vegetation by analysis of its cover

An objective assessment was made of the vegetation cover expressed as a percentage of the vertical extension of the vegetation formations (Table 1), following two procedures:

L. The percentage of total vegetation cover (\% extension of vertical vegetation shading) was evaluated on a national scale. This was done using the data from the Spanish Forestry Vegetation map (DGCN, $2004 \mathrm{~b}$ ). In the areas for which no information was available, the Corine Land Cover map was used; its legend provides an estimate of the minimum and maximum vegetation cover for the different units, and an average value was assigned for the cover for each of these units.

II. The percentage of total forest cover (\% extension of vertical tree canopy shading) was assessed on a national scale, following the procedure described above. To define the category of 'forests', we followed the criteria used in both maps, which take the minimum threshold to be $30 \%$ cover by trees of over $5 \mathrm{~m}$ in height.

\subsubsection{Step 4: Objective assessment of territorial singularity}

In order to safeguard biodiversity, we assessed the territorial singularity of the different categories or classes in the Habitats, Corine
Land Cover, Landscape and Soil maps (Table 1). This was done using an objective classification of their units calculated with the SIG. The following index of singularity was applied (Ramos, 1979; MMA 2000):

$S=\operatorname{Ln}\left(\left(1-\left(\frac{\operatorname{Max}-x}{\operatorname{Max}-\operatorname{Min}}\right)\right) \times 100+1\right)$

where $S=$ territorial singularity index; $M a x=H a$. of the map's largest category: $\operatorname{Min}=\mathrm{Ha}$. of the map's smallest category; and $x=\mathrm{Ha}$. of the map category being evaluated.

Singularity was assessed on a logarithmic scale. This transformation made it possible to maximize the value of the categories with smaller areas, and also to obtain a scale with fewer units. Thus the category with the greatest surface area was awarded the lowest singularity value (0) and the category with the least surface area was awarded the maximum value (4.62). This continuous scale was then transformed into a discrete scale of five classes, which were obtained by rounding each decimal value up to the next whole number. We thus obtained a higher singularity value for the least represented classes in the territory, in order to safeguard biodiversity.

In the case of the Corine Land Cover map, we carried out a double singularity analysis. First we estimated the singularity relating to Spain, which constitutes the main singularity scale. This scale was then refined by making a second calculation of singularity using the Corine Land Cover map for the whole of Europe. This increased the singularity value for those categories whose presence in Europe is concentrated in the Iberian Peninsula (over $40 \%$ ), as well as for those categories of Corine Land Cover which are very scarce in Europe as a whole, regardless of their abundance in Spain.

\subsubsection{Step 5: Objective assessment of habitat sizes}

Gontier et al. (2006) indicate that habitat loss is a major threat to biodiversity. Environmental impact assessment and strategic environmental assessment are essential instruments used in physical planning to address such problems. Yet there are no well-developed methods for quantifying and predicting impacts on habitat loss. These authors also highlight the gap existing between research in GIS-based ecological modelling and current practice in biodiversity assessment within environmental assessment.

We evaluated the habitat sizes of the different categories or classes in the Habitats map, and of the polygons with forest cover (identified with the Spanish Forestry and Corine Land Cover maps) (Table 1). This was done using an objective classification of their units calculated with the SIG. The following procedure was used (Ramos, 1979; MMA, 2000):

L. We calculated the surface area of each of the polygons on these maps in order to give a positive valuation to those with a greater surface area for each category or class, so as to provide more protection for the most representative polygons in each class and to favour the conservation of natural areas.

II. The valuation was done by assigning a scale of four discrete values which correspond to each of the four percentiles of the numeric distribution of frequencies of surface sizes:

Il.a. Habitat size class $1=$ sizes of polygons corresponding to the first percentile ( $0-25 \%)$ of the distribution of frequencies of sizes.

II.b. Habitat size class $2=$ sizes of polygons corresponding to the second percentile $(25-50 \%)$.

Il.c. Habitat size class $3=$ sizes of polygons corresponding to the third percentile ( $50-75 \%)$.

II.d. Habitat size class $4=$ sizes of polygons corresponding to the fourth percentile $(75-100 \%)$.

The greatest value of the habitat size variable was assigned to the polygons in the fourth percentile, which correspond to the largest polygons for each class or category of the map. 


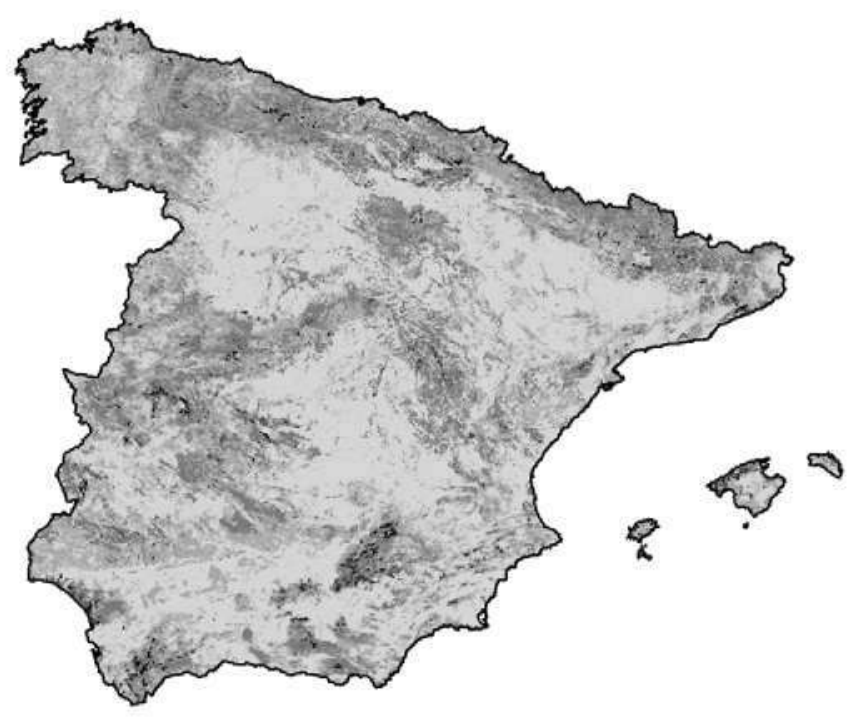

Fig. 1. GIS model for biodiversity and environmental assessment for the whole of Spain. Metadata: European projection standard Lambert Equal Area and Datum ETRS89. $100 \mathrm{~m}$ pixel-raster maps. Model scale: 1:500,000. Colour codes: classes of natural quality 1 and 2 = light grey; class of natural quality $3=$ grey; class of natural quality $4=$ dark grey: class of natural quality $5=$ black.

\subsubsection{Step 6: Normalization of the 12 variables}

The 12 variables were then normalized to avoid overlapping during their subsequent integration into the model. Normalization consisted of changing the original valuation scale for each variable, which was transformed into a common final continuous scale from 0 to 1 for all the variables. This was done by means of an equation applied to the original discrete scales and another equation applied to the original continuous scales (Mancebo et al., 2005). The following formula was used to convert the discrete scales into a continuous scale from 0 to 1 :

$X n=\left(\frac{x-0.5}{\operatorname{Max}}\right)$.
The following equation was used to transform a continuous scale into another normalized continuous scale from 0 to 1 :

$X n=\left(\frac{x-\operatorname{Min}}{\operatorname{Max}-\operatorname{Min}}\right)$.

\subsubsection{Step 7: Integration of the 12 variables into the model}

The 12 normalized raster variables were integrated using GIS combine operations. Each pixel of 1 ha of territory was assigned a vector with the 12 natural variables valued. We obtained $n$ vectors distributed among the 50 million 1-ha pixels in Spain.

The next step was to order the $n$ vectors using the modulus or Euclidean distance, to assign a synthetic value of theoretical biodiversity and environmental quality. The vector was used to order the $n$ vectors obtained based on their components, and:

$v=\sqrt{v_{1}^{2}+\ldots+v_{i}^{2}+\ldots+v_{12}^{2}} \quad i=1 \ldots 12$

where $v$ is the vector modulus; and $v_{\mathrm{i}}$ is a vector component.

A total of 102,240 different vectors were obtained with 12 components, assigned to each of the 50 million 1-ha grid squares for Spain. Then the values obtained for each of the $n$ Euclidean distances were normalized into five equivalent classes, corresponding to the five types of theoretical biodiversity and environmental quality ( 1 to 5 ). This normalized classification was obtained by applying the following formula:

Biodiversity quality class $=\left(\left(v-v_{\text {Min }}\right) /\left(v_{\text {Max }}-v_{\text {Min }}\right)\right)^{*}(5+0.5)(5)$

where $v$ is the vector modulus of each of the $n$ vectors obtained; $v_{\text {Min }}$ is the minimum vector modulus obtained; $v_{\operatorname{Max}}$ is the maximum vector modulus obtained; the very low biodiversity and environmental quality class is obtained when $0.5<v<1.5$; low quality class when $1.5<v<2.5$; moderate quality class when $2.5<v<3.5$; high quality class when $3.5<v<4.5$; and very high quality class when $4.5<v<5.5$.

Table 2

Checklist and synthetic environmental impact values based in García-Montero et al. (2008) to estimate the relative impact of 27 types of infrastructure construction project on the local environment (Impact class $0=$ compatible; Impact class $1=$ moderate; Impact class $2=$ severe; Impact class $3=$ critical).

\begin{tabular}{|c|c|c|c|c|c|c|c|c|c|c|c|}
\hline 27 types of construction project & Geology & Soil & Hydrology & Hydrogeology & Air quality & Flora & Fauna & Landscape & Climate & Biodiversity & Material assets \\
\hline New roads: urban highways & 0 & 0 & 0 & 0 & 2 & 0 & 0 & 1 & 1 & 0 & 3 \\
\hline New roads: type-III regional highways & 2 & 2 & 2 & 2 & 1 & 2 & 2 & 2 & 0 & 2 & 2 \\
\hline New roads: type-II regional highways & 2 & 2 & 2 & 2 & 1 & 2 & 2 & 2 & 0 & 2 & 2 \\
\hline New roads: type-I regional highways & 3 & 3 & 3 & 3 & 2 & 2 & 2 & 3 & 1 & 2 & 2 \\
\hline New roads: national A-roads & 3 & 3 & 3 & 3 & 3 & 2 & 3 & 3 & 1 & 2 & 3 \\
\hline New roads: dual carriageways & 3 & 3 & 3 & 3 & 3 & 3 & 3 & 3 & 2 & 3 & 3 \\
\hline New roads: motorways & 3 & 3 & 3 & 3 & 3 & 3 & 3 & 3 & 2 & 3 & 3 \\
\hline New conventional train & 2 & 3 & 2 & 2 & 1 & 2 & 2 & 2 & 1 & 2 & 2 \\
\hline New high-speed train (AVE) & 3 & 3 & 3 & 3 & 1 & 3 & 3 & 3 & 1 & 3 & 3 \\
\hline Urban highway to dual carriageway & 1 & 1 & 1 & 1 & 2 & 1 & 0 & 1 & 1 & 1 & 3 \\
\hline Urban highway to motorway & 1 & 1 & 1 & 1 & 2 & 1 & 0 & 1 & 1 & 1 & 3 \\
\hline Regional highway-III to regional highway-II & 1 & 1 & 1 & 1 & 1 & 1 & 1 & 1 & 0 & 1 & 0 \\
\hline Regional highway-III to regional highway-I & 1 & 1 & 1 & 2 & 1 & 2 & 1 & 1 & 1 & 2 & 1 \\
\hline Regional highway-III to national A road & 1 & 1 & 1 & 2 & 1 & 2 & 1 & 1 & 1 & 2 & 1 \\
\hline Regional highway-III to dual carriageway & 2 & 2 & 2 & 3 & 2 & 3 & 3 & 2 & 2 & 3 & 3 \\
\hline Regional highway-III to motorway & 3 & 3 & 3 & 3 & 3 & 3 & 3 & 3 & 2 & 3 & 3 \\
\hline Regional highway-II to regional highway-I & 1 & 1 & 1 & 1 & 1 & 1 & 1 & 1 & 0 & 2 & 1 \\
\hline Regional highway-II to national A road & 1 & 1 & 1 & 1 & 1 & 1 & 1 & 1 & 0 & 2 & 1 \\
\hline Regional highway-ll to dual carriageway & 2 & 2 & 2 & 3 & 3 & 3 & 3 & 2 & 2 & 3 & 3 \\
\hline Regional highway-II to motorway & 3 & 3 & 3 & 3 & 3 & 3 & 3 & 3 & 2 & 3 & 3 \\
\hline Regional highway-I to national A road & 1 & 1 & 1 & 1 & 1 & 2 & 2 & 1 & 1 & 1 & 1 \\
\hline Regional highway-I to dual carriageway & 2 & 2 & 2 & 2 & 2 & 3 & 3 & 2 & 1 & 3 & 3 \\
\hline Regional highway-I to motorway & 2 & 3 & 2 & 3 & 2 & 3 & 3 & 3 & 1 & 3 & 3 \\
\hline National A road to dual carriageway & 2 & 2 & 2 & 3 & 2 & 3 & 3 & 2 & 1 & 2 & 2 \\
\hline National A road to motorway & 2 & 2 & 2 & 3 & 2 & 3 & 3 & 2 & 1 & 3 & 3 \\
\hline Dual carriageway to motorway & 1 & 1 & 1 & 1 & 1 & 1 & 1 & 0 & 0 & 1 & 0 \\
\hline Conventional train to AVE & 2 & 2 & 2 & 2 & 0 & 2 & 3 & 3 & 1 & 3 & 1 \\
\hline
\end{tabular}


Table 3

Synthetic environmental impact of 27 types of construction project (based in García-Montero et al., 2008).

\begin{tabular}{|c|c|c|c|c|c|}
\hline 27 types of construction project & Vector module & Normalization & Maximum level of potential impact & Potential impact codes & Impact types \\
\hline Dual carriageway to motorway & 2.1 & 0.5 & $(<1.5)$ & 1 & Compatible \\
\hline Regional highway-III to regional highway-II & 3.0 & 1.0 & $(<1.5)$ & 1 & Compatible \\
\hline Regional higliway-II to regional higliway-I & 3.8 & 1.4 & $(<1.5)$ & 1 & Compatible \\
\hline Regional ligliway-II to national A road & 3.8 & 1.4 & $(<1.5)$ & 1 & Compatible \\
\hline New roads: urban highways & 4.0 & 1.5 & $(1.5-2.5)$ & 2 & Moderate \\
\hline Urban ligilway to dual carriageway & 4.4 & 1.7 & $(1.5-2.5)$ & 2 & Moderate \\
\hline Urban highway to motorway & 4.4 & 1.7 & $(1.5-2.5)$ & 2 & Moderate \\
\hline Regional highway-I to national A road & 4.4 & 1.7 & $(1.5-2.5)$ & 2 & Moderate \\
\hline Regional highway-III to regional highway-I & 4.8 & 1.9 & $(1.5-2.5)$ & 2 & Moderate \\
\hline Regional highway-III to national A road & 4.8 & 1.9 & $(1.5-2.5)$ & 2 & Moderate \\
\hline New roads: type-III regional highways & 6.1 & 2.6 & $(2.5-4.0)$ & 3 & Severe \\
\hline New conventional train & 6.4 & 2.7 & $(2.5-4.0)$ & 3 & Severe \\
\hline Conventional tain to AVE & 6.6 & 2.8 & $(2.5-4.0)$ & 3 & Severe \\
\hline New roads: type-II regional highways & 6.6 & 2.8 & $(2.5-4.0)$ & 3 & Severe \\
\hline National A road to dual carriageway & 7.5 & 3.3 & $(2.5-4.0)$ & 3 & Severe \\
\hline National A road to motorway & 7.8 & 3.5 & $(2.5-4.0)$ & 3 & Severe \\
\hline Regional highway-I to dual carriageway & 7.9 & 3.5 & $(2.5-4.0)$ & 3 & Severe \\
\hline New roads: type-I regional highways & 7.9 & 3.5 & $(2.5-4.0)$ & 3 & Severe \\
\hline Regional ligliway-I to motorway & 8.2 & 3.7 & $(2.5-4.0)$ & 3 & Severe \\
\hline Regional higlwway-II to dual carriageway & 8.3 & 3.7 & $(2.5-4.0)$ & 3 & Severe \\
\hline Regional highway-III to dual carriageway & 8.4 & 3.8 & $(2.5-4.0)$ & 3 & Severe \\
\hline New roads: national A-roads & 8.7 & 3.9 & $(2.5-4.0)$ & 3 & Severe \\
\hline Regional highway-II to motorway & 8.7 & 4.0 & $(2.5-4.0)$ & 3 & Severe \\
\hline New high-speed train (AVE) & 8.8 & 4.1 & $(>4)$ & 4 & Critical \\
\hline Regional highway-III to motorway & 8.9 & 4.1 & $(>4)$ & 4 & Critical \\
\hline New roads: dual carriageways & 9.8 & 4.5 & $(>4)$ & 4 & Critical \\
\hline New loads: motorways & 9.8 & 4.5 & $(>4)$ & 4 & critical \\
\hline
\end{tabular}

The 27 vector modules were calculated and normalized, to assign each of the 27 construction projects a synthetic value of potential impact in four equivalent classes (Impact class $1=$ compatible; Impact class 2 = moderate; Impact class $3=$ severe; Impact class $4=$ critical).

Normalization $=\mid(x-\operatorname{Min} / \operatorname{Max}-\operatorname{Min}) \times 4) \mid+0.5$.

García-Montero et al. (2010) have proposed 100 classes of environmental quality in the Spanish territory based in the LATINO model (LArge Territory Integrated eNvirOnmental model). However, in the present study, the use of five classes of biodiversity and environ- mental quality is sufficient for a screening, as this is a preliminary classification which clearly distinguishes extreme cases of high and low biodiversity and environmental quality of a territory on a nationwide scale.

Table 4

Model of a double-entry evaluation matrix integrating the 5 classes of biodiversity quality ( $1=$ very low, $2=$ low, $3=$ average, $4=$ high, $5=$ very high) with the 4 synthetic value of potential environmental impact levels ( $1=$ compatible; $2=$ moderate; $3=$ severe; $4=$ critical) for the 27 construction projects ( 12 -km bands) based in García-Montero et al. (2008).

\begin{tabular}{|c|c|c|c|c|c|c|}
\hline 27 types of constuction project & Potential impact codes & Class quality 1 & Class quality 2 & Class quality 3 & Class quality 4 & Class quality 5 \\
\hline Dual calriageway to motolway & 1 & 1 & 1 & 1 & 2 & 4 \\
\hline Regional higliway-III to regional higliway-II & 1 & 1 & 1 & 1 & 2 & 4 \\
\hline Regional higliway-II to regional higlwway-I & 1 & 1 & 1 & 1 & 2 & 4 \\
\hline Regional ligliway-II to national A road & 1 & 1 & 1 & 1 & 2 & 4 \\
\hline New roads: urban highways & 2 & 1 & 1 & 2 & 3 & 4 \\
\hline Urban highway to dual carriageway & 2 & 1 & 1 & 2 & 3 & 4 \\
\hline Urban highway to motorway & 2 & 1 & 1 & 2 & 3 & 4 \\
\hline Regional highway-I to national A road & 2 & 1 & 1 & 2 & 3 & 4 \\
\hline Regional higlwway-III to regional higlwway-I & 2 & 1 & 1 & 2 & 3 & 4 \\
\hline Regional higliway-III to national A road & 2 & 1 & 1 & 2 & 3 & 4 \\
\hline New roads: type-III regional highways & 3 & 1 & 2 & 3 & 4 & 4 \\
\hline New conventional train & 3 & 1 & 2 & 3 & 4 & 4 \\
\hline Conventional train to AVE & 3 & 1 & 2 & 3 & 4 & 4 \\
\hline New roads: type-II regional highways & 3 & 1 & 2 & 3 & 4 & 4 \\
\hline National A road to dual carriageway & 3 & 1 & 2 & 3 & 4 & 4 \\
\hline National A rodd to motolway & 3 & 1 & 2 & 3 & 4 & 4 \\
\hline Regional higliway-I to dual carriageway & 3 & 1 & 2 & 3 & 4 & 4 \\
\hline New roads: type-I regional highways & 3 & 1 & 2 & 3 & 4 & 4 \\
\hline Regional higliway-I to motorway & 3 & 1 & 2 & 3 & 4 & 4 \\
\hline Regional highway-II to dual carriageway & 3 & 1 & 2 & 3 & 4 & 4 \\
\hline Regional highway-III to dual carriageway & 3 & 1 & 2 & 3 & 4 & 4 \\
\hline New roads: national A-roads & 3 & 1 & 2 & 3 & 4 & 4 \\
\hline Regional highway-II to motorway & 3 & 1 & 2 & 3 & 4 & 4 \\
\hline New ligh-speed train (AVE) & 4 & 1 & 3 & 4 & 4 & 4 \\
\hline Regional higliway-III to motorway & 4 & 1 & 3 & 4 & 4 & 4 \\
\hline New roads: dual carriageways & 4 & 1 & 3 & 4 & 4 & 4 \\
\hline New roads: motorways & 4 & 1 & 3 & 4 & 4 & 4 \\
\hline
\end{tabular}


Table 5

Travel-time savings and estimated induced traffic.

\begin{tabular}{lllllll}
\hline \multirow{2}{*}{$\begin{array}{l}\text { Transport } \\
\text { mode }\end{array}$} & \multicolumn{3}{l}{ Location indicator (min) } & & \multicolumn{2}{l}{ Induced traffic (\%) } \\
\cline { 2 - 4 } & $\begin{array}{l}\text { Do-nothing } \\
\text { alternative }\end{array}$ & $\begin{array}{l}\text { PEIT } \\
\text { alternative }\end{array}$ & $\begin{array}{l}\text { Reduction } \\
(\%)\end{array}$ & & Minimum & Maximum \\
\hline Road & 156.8 & 153.2 & 2.3 & & 1.1 & 4.6 \\
Rail & 325.8 & 213.9 & 34.4 & & 58.4 & 92.7 \\
\hline
\end{tabular}

Table 6

GIS raster model for biodiversity and environmental assessment.

\begin{tabular}{lcl}
\hline Natural quality class & Extensions of territory (ha) & Extensions of territory (\%) \\
\hline Quality class 1 & $9,110,329$ & 18.3 \\
Quality class 2 & $14,962,451$ & 30.0 \\
Quality class 3 & $15,522,632$ & 31.1 \\
Quality class 4 & $9,673,891$ & 19.4 \\
Quality class 5 & 588,741 & 1.2 \\
\hline
\end{tabular}

This model classifies the Spanish territory into 5 classes of biodiversity and environmental quality (Mancebo et al., 2005; García-Montero et al., 2010),

2.3. First screening tool for assessing the impact of the PEIT on Spanish biodiversity and environment

\subsubsection{Step 1: Integration with the infrastructures map}

We established which zones would be most directly affected by the roads and railway lines in the PEIT 2005-2012. This operation was done by means of an analysis with the GIS, in which the scenario of the linear infrastructures existing in 2005 (scenario 0) was compared to the linear infrastructures planned for 2012. Then we defined and mapped $12-\mathrm{km}$-wide corridors or potential impact bands around each of the new infrastructures in the PEIT ( $2 \mathrm{~km}$ to compensate for lack of map definition, and $10 \mathrm{~km}$ of territory potentially affected by each infrastructure). These corridors represent areas with a high risk of environmental impact caused by the PEIT (Fig. 1). Five-km $(+1)$ bands were selected at each side of the routes planned in the PEIT, based on a comparison with other environmental impact studies for several linear infrastructure projects (Ramos, 1979; Otero et al., 1999; MMA, 2000; García-Montero et al., 2008). Moreover, we have repeated the same GIS screening models using 24-km-wide corridors or potential impact bands around each of the new infrastructures in the PEIT, to compare $12-\mathrm{km}$ versus $24-\mathrm{km}$-wide corridors. The future environmental impact in these corridors was assumed to be uniform across the whole width of the band.

Within the $12-\mathrm{km}$ corridors around the infrastructures, we located and represented the five classes of biodiversity and environmental quality of the territory shown on the 1:500,000 map of Spain. This integration generated a raster map with the biodiversity and environmental quality values of the areas which are potentially affected by the new roads and railways planned in the PEIT.

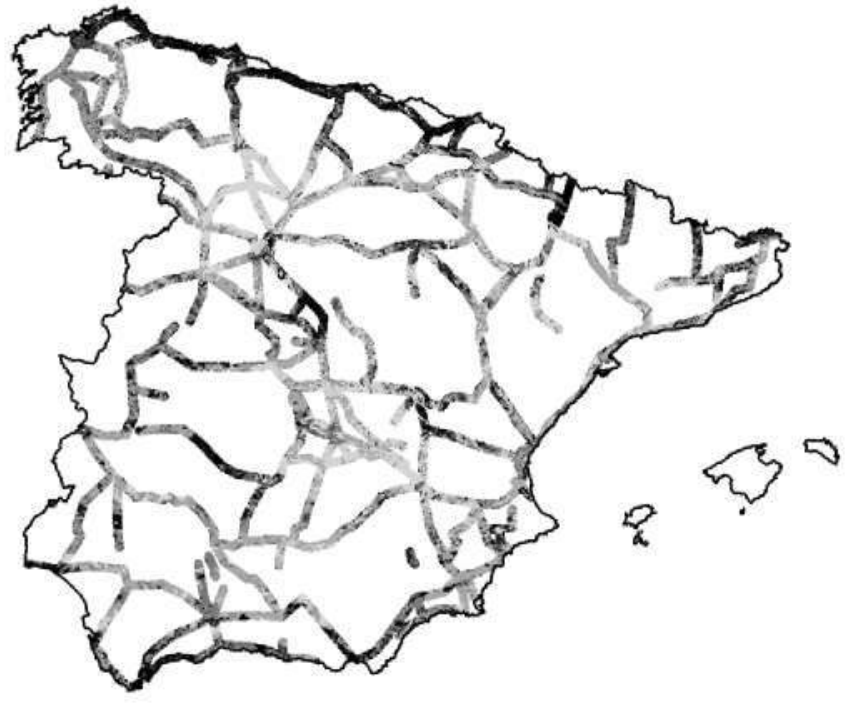

Fig. 2. Potential impact map: result of screening model for assessing the impact of PEIT infrastructures on Spanish biodiversity and environment (only 12-km-wide corridors around each of the new infrastructures in the plan are defined and mapped). Metadata: European projection standard Lambert Equal Area and Datum ETRS89. $100 \mathrm{~m}$ pixel-raster maps. Colour codes: compatible potential impact $=$ light grey: moderate potential impact = grey; severe potential impact $=$ dark grey; critical potential impact $=$ black

2.3.2. Step 2: Creation of a rapid checklist of the synthetic potential environmental impact of the construction projects planned

We identified 27 types of construction project in the PEIT 20052012. We have created a checklist to estimate their potential environmental impact (with values of between 0 and 3 ) based in García-Montero et al. (2008) (Table 2). This checklist was drawn up by consulting 10 expert researchers on transport subjects (panel of experts) from the Transport Research Centre TRANSyT at the Technical University of Madrid (UPM) and the Complutense University of Madrid. The checklist was made using the vector modulus and Analytical Hierarchy (Saaty, 1980) by lining up each of the 27 types of construction project or alternatives planned in the PEIT with each of the elements in the local environment listed in SEA European Directive 2001/42/EC (Table 3).

2.3.3. Step 3: Integration of the synthetic potential environmental impact checklist in the biodiversity and environmental quality for the $12-\mathrm{km}$ corridors around the infrastructures

The last step in this first screening model was to integrate the five classes of biodiversity and environmental quality (very low, low, average, high, very high) mapped in the $12-\mathrm{km}$ corridors around the infrastructures with the four synthetic potential environmental impact levels ( 1 to 4 ) for the 27 construction projects in the checklist. This integration was done using as a model a double-entry evaluation matrix based on

Table 7

Extensions of Spanish territory which may be affected by the PEIT 2005-2012 plan, with the different degrees of potential environmental impact using 12-km versus 24-km-wide corridors around each of the new infrastructures in the PEIT.

\begin{tabular}{llll}
\hline Environmental impact class & $\begin{array}{l}\text { Total extension (ha) } \\
\text { potentially affected } \\
\text { using 12-km-wide } \\
\text { corridors }\end{array}$ & $\begin{array}{l}\text { Relative \% of area within } \\
\text { the areas potentially affected } \\
\text { using 12-km-wide corridors }\end{array}$ & $\begin{array}{l}\text { Total extension (ha) } \\
\text { potentially affected } \\
\text { using 24-km-wide } \\
\text { corridors }\end{array}$ \\
\hline Compatible potential impact & $3,256,811$ & 23.2 & $\begin{array}{l}\text { Relative \% of area within } \\
\text { the areas potentially affected } \\
\text { using 24-km-wide corridors }\end{array}$ \\
Moderate potential impact & $3,928,807$ & 28.0 & $5,471,659$ \\
Severe potential impact & $3,923,072$ & 28.0 & $6,781,293$ \\
Critical potential impact & $2,921,801$ & 20.8 & $6,978,923$ \\
\hline
\end{tabular}


García-Montero et al. (2008) (Table 4), which was applied only in the 12$\mathbf{k m}$ bands around the infrastructures. The criteria applied in this evaluation matrix were the optimization of the maximum protection of the pixels in the territory (1 ha) with the greatest biodiversity and environmental quality and the lowest incidence in Spanish territory; as opposed to the lower protection of the pixels with less biodiversity and environmental quality and greater frequency. These criteria are connected to those of Treweek et al. (1998), Brown (2003) and Schumaker et al. (2004). This evaluation matrix allowed us to propose as a final result four potential impact classes of the PEIT 2000-2007 on biodiversity and environment $(1=$ compatible; $2=$ moderate; $3=$ severe; 4 = critical) (Table 4 ) within these $12-\mathrm{km}$ bands.

2.4. Second screening tool for assessing the impact of the PEIT on giobal warming

\subsubsection{Step 1: Travel demand forecasts}

López (2007) indicated that a national transport model is not available in Spain to date, although its development is currently on the Spanish research agenda (ETT and EPYPSA, 2006). This fact made it difficulc to calculate the total $\mathrm{CO}_{2}$ emissions in each alternative of an infrastructure plan. Therefore, a simplification has been made in order to obtain an approximate value of these emissions.

It is well reported that induced travel is an important component of travel demand (Goodwin, 1996; Guirao, 2000; Cervero and Hansen, 2002; Lee, 2002; Litman, 2004). With improved transportation conditions, short-term effects (e.g., route switches, mode switches, changes of destination, and new trip generation) and long-term effects (e.g., change in household car ownership, and spatial reallocation of activities) will be observed.

Many studies have estimated travel-time elasticities - mostly related to highway expansions -, but one of the difficulties in interpreting these results is the uncertainty of the time frame that is applicable to the data (Lee, 2002). The value of the elasticity of the transport demand is obtained by calculating the percentage by which travel demand varies when another variable (normally travel time) varies by $1 \%$ (López, 2007). Goodwin (1996), Noland and Lem (2002) and Cervero and Hansen (2002) provide reviews of many empirical studies on induced demand due to road capacity expansions. For example, Goodwin (1996) found that proportional savings in travel time were matched by proportional increases in traffic on almost a one-to-one basis. Other works suggest an average value for the elasticity of travel volume with respect to travel time of about -0.5 to -1.0 in the short term (these values signify that a $1 \%$ increase in travel time translates into a $0.5-1.0 \%$ reduction in demand), and up to -2.0 in the long term (Lee, 2002).

Rail-related studies are less common. They mostly agree that demand for rail services is much more sensitive to changes in cost and travel time than the demand for automobile travel. Morrison and Winston (1985) found that rail demand is elastic with respect to time, estimating it as -1.67 for business trips and -1.58 in vacation trips. Bel (1997) carried out a study with Spanish data and estimated rail travel-time elasticities of -2.66 (for daytime traffic trains below $400 \mathrm{~km}$ ) and -2.37 for trips over $400 \mathrm{~km}$. Other works of intercity
Table 9

Forecast induced traffic and corresponding increases in GHG emissions: do-nothing vs. PEIT alternative (road and rail modes); TREMOVE 2.44 MODEL (Transport \& Mobility Leuven and K.U. Leuven, 2006)

\begin{tabular}{|c|c|c|c|c|}
\hline & & & Road & Rail \\
\hline \multirow[t]{4}{*}{$\begin{array}{l}\text { Traffic } \\
\quad \text { (million vkm) }\end{array}$} & $\begin{array}{l}\text { Do-nothing } \\
\text { alternative }\end{array}$ & & 332,359 & 275 \\
\hline & PEIT altemative & Minimum & 336,082 & 436 \\
\hline & & Maximum & 347,714 & 531 \\
\hline & & Mean & 340,037 & 370 \\
\hline \multirow[t]{4}{*}{$\begin{array}{l}\text { GHG emissions } \\
\quad\left(\mathrm{t} \mathrm{CO}_{2}\right)\end{array}$} & $\begin{array}{l}\text { Do-nothing } \\
\text { altemative }\end{array}$ & & $72,513,766$ & 234,275 \\
\hline & PEIT altemative & Minimum & $73,279,001$ & 365,756 \\
\hline & & Maximum & $75,670,365$ & 442,987 \\
\hline & & Mean & $74,474,684$ & 404,371 \\
\hline \multirow{9}{*}{$\begin{array}{l}\text { Increase in GHG } \\
\text { emissions }\end{array}$} & Absolute $\left(\mathrm{t} \mathrm{CO}_{2}\right)$ & Minimum & 765,235 & 131,481 \\
\hline & & Maximum & $3,156,599$ & 208,712 \\
\hline & & Mean & $1,960,918$ & 170,096 \\
\hline & Relative ${ }^{a}(\%)$ & Minimum & 1.0 & 56.1 \\
\hline & & Maximum & 4.4 & 89.0 \\
\hline & & Mean & 2.7 & 72.6 \\
\hline & Global relative ${ }^{b}(\%)$ & Minimum & 1.0 & 0.2 \\
\hline & & Maximum & 4.3 & 0.3 \\
\hline & & Mean & 2.7 & 0.2 \\
\hline
\end{tabular}

* Percentage change of each mode's emissions of the do-nothing alternative.

b Percentage change of total road and rail emissions of the do-nothing alternative.

HSR projects planned in Japan, computing short term induced travel elasticities, are presented by Yao and Morikawa (2005). In summary. for the rail mode "across all relations, account being taken of the weight of each relation, an approximate travel-time elasticity of -2.2 emerges' (Savelberg and Vogelaar, 1987).

To compensate for this uncertainty in forecasts of travel demand. rather than taking a single value for travel-time elasticities, a range of -0.5 to -2.0 will be used for the road mode, and -1.7 to -2.7 for the rail mode.

\subsubsection{Step 2: Calculation of travel-time savings}

The approach used to compute travel-time savings is based on the calculation of accessibility indicators. The selected formulation is that of the location accessibility indicator, a 'travel cost indicator' (López, 2007), which computes average travel time to the set of destinations. This indicator was previously used in similar studies at the Spanish national level (Monzón et al., 2005). The formulation chosen is included in Eq. (6).

$L_{i}=\sum_{j} \frac{I_{i j} P_{j}}{\sum_{j} P_{j}}$

The location indicator $\left(L_{\mathrm{j}}\right)$ was computed as the average travel time (in minutes) to the set of destinations, using the population of each destination as the weighting variable.

The set of destinations includes locations in Portugal and the three southern regions of France. The location indicator is therefore used as a proxy for the evaluation of travel-time savings, when its results in the PEIT 2005-2012 alternative are compared to those of the do-

Table 8

Extensions of Spanish territory which may be affected by the plans PIT 2000-2007 (Garcia-Montero et al., 2008) and PEIT 2005-2012, with the different degrees of potential environmental impact (using 12-km-wide corridors around each of the new infrastructures).

\begin{tabular}{llll}
\hline Environmental impact class & $\begin{array}{l}\text { Total extension (ha) } \\
\text { potentially affected by } \\
\text { the PIT 2000-2007 }\end{array}$ & $\begin{array}{l}\text { Relative \% of area within } \\
\text { the areas potentially affected } \\
\text { by the PIT 2000-2007 }\end{array}$ & $\begin{array}{l}\text { Total extension (ha) } \\
\text { potentially affected by } \\
\text { the PEIT 2005-2012 }\end{array}$ \\
\hline Compatible potential impact & $3,549,288$ & 25.5 & $\begin{array}{l}\text { Relative \% of area within } \\
\text { the areas potentially affected } \\
\text { by the PEIT 2005-2012 }\end{array}$ \\
Moderate potential impact & $4,955,127$ & 35.6 & $3,256,811$ \\
Severe potential impact & $1,892,566$ & 13.6 & $3.928,807$ \\
Critical potential impact & $3,517,960$ & 25.3 & $3,923,072$ \\
\hline
\end{tabular}


nothing alternative. Hence, a single aggregated value of the location indicator for all Spain has been computed and compared to that of the do-nothing alternative. The calculation, in percentage changes, has been translated into the corresponding increases in travel demand by using the range of travel-time elasticities cited above (Table 5).

2.4.3. Step 3: Computation of the global warming performance indicator The next step in the second screening tool (GHG emissions screening tool) is the calculation of the performance indicator, which consists of transforming the estimated increase in travel demand into the corresponding increase in GHG emissions. This estimation was done with version 2.44 of the TREMOVE model (Transport \& Mobility Leuven and K.U. Leuven, 2006). TREMOVE is a policy assessment model designed to study the effects of different transport and environment policies on transport sector emissions.

The model estimates the transport demand, the modal split, the vehicle fleets, the emissions of air pollutants and the welfare level under different policy scenarios. All relevant transport modes are modelled. TREMOVE models both passenger and freight transport, and covers the period 1995-2020. TREMOVE consists of 21 parallel country models. Each country model consists of three inter-linked 'core' modules: a transport demand module, a vehicle turnover module and an emission and fuel consumption module, to which a welfare cost module and a well-to-tank emissions module is added. This model was developed by Transport \& Mobility Leuven and the K.U. Leuven in a service contract for the European Commission, DG Environment (http:// www.tremove.org). Model runs were carried out with the data on induced traffic, resulting in the corresponding $\mathrm{CO}_{2}$ emissions.

\section{Results and conclusions}

The GIS model for biodiversity and environmental assessment classifies the Spanish territory into the 5 classes of biodiversity and environmental quality shown in Table 6 and Fig. 1 (Mancebo et al., 2005; García-Montero et al., 2010). The application of distribution frequencies for each of the quality classes appears to be a suitable approach for use in developing an infrastructure plan, and for incorporating the map of biodiversity and environmental quality into its planning procedures. This model shows that the planning of infrastructures would be permitted in $48.3 \%$ of Spanish territory (Table 6), as this would affect grid squares with low quality values (classes 1 and 2). However the planning of infrastructures could not

\section{MODEL 1. A GIS model for biodiversity and environmental assessment (LATINO model)}
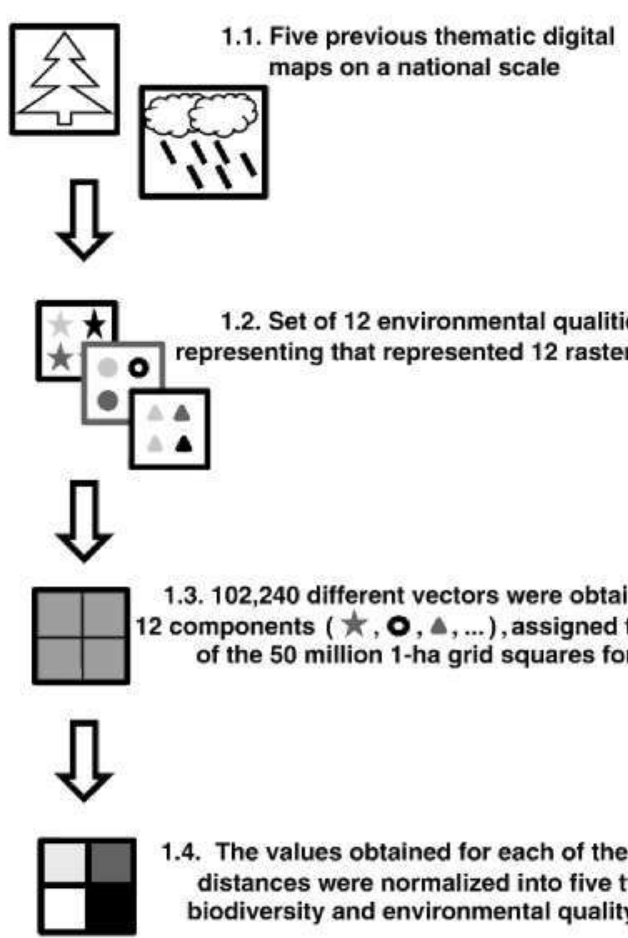

1.2. Set of 12 environmental qualities representing that represented 12 raster layers

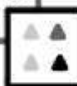

1.3. 102,240 different vectors were obtained with 2 components $(\star,, 0, \Delta, \ldots)$, assigned to each of the $\mathbf{5 0}$ million 1-ha grid squares for Spain

1.4. The values obtained for each of the $n$ Euclidean distances were normalized into five types of biodiversity and environmental quality (1 to 5 )<smiles>[Tl]</smiles>

1.5. Map of environmental quality in the Spanish territory (LATINO model)
MODEL 2. Assessment model of the potential environmental impact of the planned construction projects

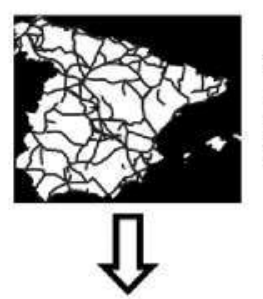

2.1. We defined and mapped 12-kmwide corridors or potential impact

bands around each of the new

infrastructures in the PEIT 2005-2012

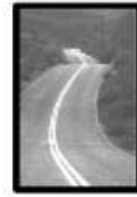

2.2. We identified 27 types of construction project in the PEIT 2005-2012

2.3. We created a checklist to estimate the potential environmental impact of 27 types of construction project (panel of experts)
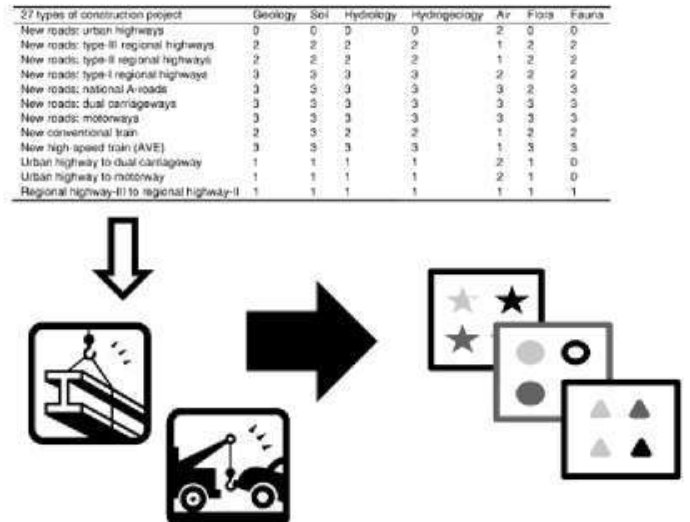

2.4. The checklist was made using the vector modulus and Analytical Hierarchy by lining up each of the 27 types of project with each of the elements in the local environment listed in SEA European Directive 
be sited in $20.6 \%$ of the territory, as this would affect grid squares with high values (4 and 5) (Table 6).

The first GIS screening tool, for assessing the impact of the PEIT on Spanish biodiversity and environment, shows that the PEIT would potentially affect at least $28.1 \%$ of Spanish territory, that is to say a total of $14,030,491 \mathrm{ha}$. Such a great expanse is due to the large number of infrastructures planned. Table 7 and Fig. 2 show the expanses of Spanish territory which may be affected by the Plan, with different degrees of potential environmental impact (within the $12-\mathrm{km}$ corridors around the planned infrastructures).

The first effect that the GIS screening tool had on the planning processes of the plan was to show the high environmental risk represented by the initial PEIT proposal it contained. The first screening tool showed that at least $20.8 \%$ of the areas affected by the PEIT are subject to a high risk of 'potential critical impact' (Table 7). This means that the future Environmental Impact Assessment (EIA) procedures applied to each specific road and railway project in this infrastructure plan, in the areas indicated as 'critical' in the screening, have a high likelihood of obtaining a negative EIA declaration from the independent environmental body, which will compromise the legal feasibility of these particular projects.

The results of the GIS screening tool also highlighted other environmental errors in the design of the infrastructure plan we used as a sample case. A comparison of the different percentages of territory in the five natural quality classes in Spain with the percentages of the four classes of potential impact of the PEIT obtained for the $12-\mathrm{km}$ corridors reveals several problems:

I.- The areas which obtained an assessment of 'very low and low' biodiversity and environmental quality (classes 1 and 2 ) account for $48.3 \%$ of the Spanish territory, that is, $24,072,780$ ha (Fig. 1, Table 6). Spain has large expanses of territory whose natural environment has been drastically altered, a fact which can be explained by the Iberian Peninsula's long history of human intervention. However, the PEIT planning process has not taken advantage of these areas for routing new infrastructures.

II.- This has meant that the areas affected by the PEIT (12-km corridors) which present compatible potential impacts (class 1) only account for $23.2 \%$ of the total environmental impact. This value is clearly less than the affected areas which have a 'moderate' potential impact (class 2), representing $28.0 \%$ of the affected territory, and zones with 'severe and critical' potential impacts (classes 3 and 4), which represent $48.8 \%$.

Table 7 shows the comparison of the GIS screening results using 12 $\mathrm{km}$ versus $24-\mathrm{km}$-wide corridors or potential impact bands around each of the new infrastructures in the PEIT. The relative \% of the area within the potentially affected areas in the case of the $12-\mathrm{km}$-wide corridors is very similar to in the $24-\mathrm{km}$ corridors. These results confirm that $12-\mathrm{km}-$ wide corridors would be significant in the proposed GIS screening models, based on the scale and level of detail used.

This first screening diagnosis leads to the conclusion that the PEIT should be unequivocally subjected to a SEA procedure, and that the results of the GIS screening tool should be taken into account in the infrastructure planning process. Moreover, the GIS screening tool generated two digital maps for this plan (Figs. 1 and 2) which allowed us to locate other corridors which could more easily accommodate some new and alternative routes in a revised and improved PEIT.

A previous GIS screening tool version was applied to an earlier Spanish infrastructure plan known as PIT 2000-2007 (within the 12$\mathrm{km}$ corridors around the planned infrastructures) (García-Montero et al., 2005, 2008). The Spanish Ministry of Public Works has used the GIS screening results applied to PIT 2000-2007 to improve the current infrastructure plan known as PEIT 2005-2012 (Ministerio de Fomento, 2003, 2004). Table 8 demonstrates how the GIS screening tool applied

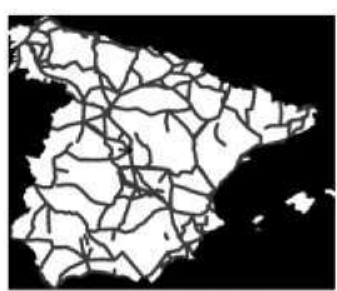

3.1. 12-km-wide corridors or potentia impact bands around each of the new infrastructures in the PEIT 2005-2012

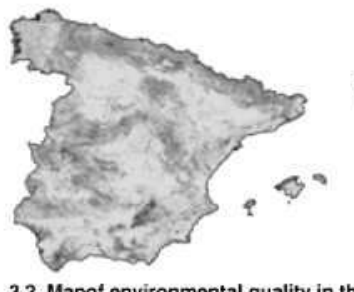

3.2. Mapof environmental quality in the Spanish territory (LATINO model)
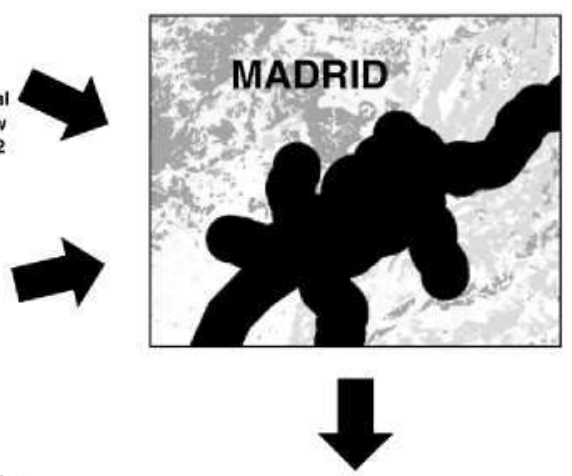

MODEL 3. GIS SCREENING TOOL: Integration of the synthetic potential environmental impact checklist with the biodiversity and environmental quality model for the 12-km corridors around the infrastructures

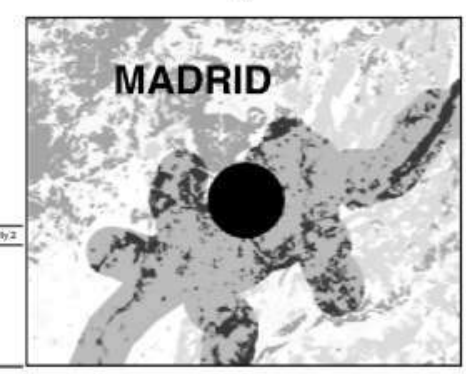

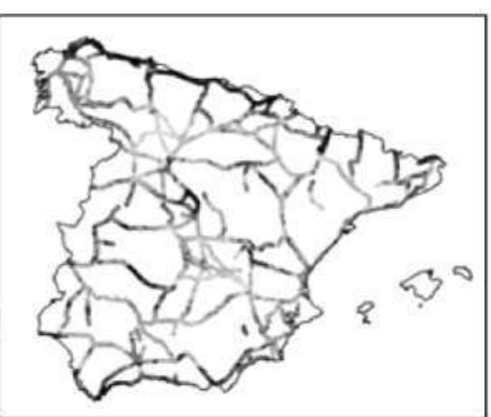

3.4. Result of GIS Screening model for assessing the impact of PEIT infrastructures on Spanish biodiversity and environment

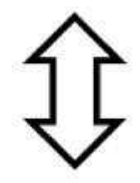

MODEL 4. EMISSIONS SCREENING TOOL

Forecast of induced traffic and corresponding increases in GHG emissions: do-nothing vs. PEIT alternative $=1,960,918$ tons of $\mathrm{CO}_{2}$

3.3. The last step in the GIS Screening Model was to integrate the 5 classes of environmental quality mappec in the 12-km corridors around the infrastructures with the 4 synthetic potential environmental impact levels in the $12-\mathrm{km}$ corridors around the infrastructures with the 4 synthetic potential environmental impact levels
$(1$ to 4$)$ for the 27 construction projects in the checklist. This integration was done using as a model a double(1 to 4 ) for the 27 construction
entry evaluation matrix.

Fig. 4. Flow chart of all the steps in the proposed screening tools (GIS screening model and GHG emissions screening tool). 
to PEIT 2005-2012 shows a smaller critical potential impact for PEIT 2005-2012 (20.8\%) than PIT 2000-2007 (25.3\%). This comparison therefore proves that the integration of the GIS screening results to generate planning alternatives is a useful mechanism for improving the importance of biodiversity and environmental quality in the decision-making process.

The results of the second screening tool for assessing the impact of the PEIT on global warming are summarized in Table 9. The donothing alternative in the road mode accounts for over 72.5 million tons of $\mathrm{CO}_{2}$. It can be seen how the mean increase in GHG emissions due to the extension of the HCR network included in the PEIT accounts for nearly 2 million tons of $\mathrm{CO}_{2}$, which represents a $2.7 \%$ increase compared to both the do-nothing alternative value for the road mode.

On the other hand, the do-nothing alternative in the rail mode accounts for only 234,000 tons. The extension of the HSR network included in the PEIT accounts for nearly 170,000 tons of $\mathrm{CO}_{2}$, which represents an increase of over $72 \%$, in terms of the do-nothing alternative value for the rail mode, whereas it represents only a $0.2 \%$ increase in total road and rail emissions in the do-nothing alternative.

The comparison of the absolute increases in $\mathrm{GHG}$ emissions between road and rail modes ( 2 million vs. 170,000 tons of $\mathrm{CO}_{2}$ ) gives an idea of the significant difference in the contribution of the above transport modes to GHG emissions, which is obviously proportional to their corresponding traffic volumes. In any case, the results of the second screening tool for assessing the impact of the PEIT on global warming confirmed the conclusion that the plan should be subjected to a SEA procedure, and showed also that the increases in GHG emissions should be taken into account in the PEIT planning process.

The methodology and selection of both tools does not enable us to determine where the most significant environmental problems are to be found. It provides us with a tool to ascertain the possible impact of a planning alternative on biodiversity and climate change. Other environmental impacts are not within the scope of this article.

In summary, we propose two screening tools whose methodologies are designed to be fast and simple. In Figs. 3 and 4 we have included some flow charts of all the steps involved in these screening tools. The environmental imbalances detected in the planning processes for the initial PEIT 2005-2012 plan in our study reveal that the planning process did not include enough environmental criteria or models. Therefore, it is very important that the two screening tools and the SEA should be integrated into the planning processes, as this will reduce the time and cost needed for the preparation of the infrastructure plan, improve their quality and reliability, and encourage public participation. It will therefore contribute to better and more transparent environmental decisionmaking, thus promoting sustainable development.

\section{Acknowledgments}

We would like to thank all the personnel at TRANSyT (UPM), Department of Soil Science at the Complutense University, S. Mancebo, M.A. Casermeiro, Margarita, Luis, Pablo and Miriam, for their support. We thank the Centro Geográfico del Ejército and authorities at the Ministerio de Defensa of Spain. The research dealt with in this article forms part of the Projects entitled "Análisis de los impactos tervitoriales producidos por los modos de transporte terrestres definidos en el Flan de infraestructuras 2002-

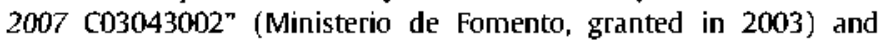
"Evaluación de los efectos del Plan de Infraestructuras 2000-2007 sobre la movilidad, el tervitorio y la socioeconomía en el contexto de la U.E. ampliada" (CyCTT, granted in 2004).

\section{References}

Alshuwaikhat HM. Strategic envirommental assessinent can help solve environmental impact assessment failures in developing countries. Environ Impac Assess Rev $2005 ; 25: 307-17$
Bel G. Changes in travel time across modes and its impact on the demand for interurban rail travel. Transport Res-E 1997;33:43-52.

Brown AL. Increasing the utility of urban envirommental quality information. Landsc Uiban Plan 2003:65:87-91.

Cervero $R$, Hansen M. Induced travel demand and induced road investment. A simultaneous equation analysis. J Transp Econ Policy 2002;36:469-90.

Chaker A. El-Fadl K. Chamas B, Hatjian A. A review of strategic envirommental assessment in 12 selected countries. Environ Impac Assess Rev 2006;26:15-56.

Dalkmann H, Herrera RJ, Bongardt D. Analytical strategic environmental assessment (ANSEA) developing a new approach to SEA. Environ Impac Assess Rev 2004;24: $385-402$.

DGCN Directión General Conservación Naturaleza. Dirección General Conservación Naturaleza. Mapas del Proyecto Hábitat. Madrid: Ministerio de Medio Ambiente: 2004a.

DGCN Dirección General Conselvación Naturaleza. Mapa Forestal Español. Madrid: Ministerio de Medio Ambiente; 2004b.

EC European Comisión. European SEA Directive 2001/42/EC; 2001. http://ec.europa.eu/ environment/eia/eia-guidelines/g-screeningfull-text.pdf.

EC European Comisión. Winning the battle against global climate change. COM (2005) 35 final; 2005.

EEA European Environmental Agency. Manual on strategic environmental assessment of transport infrastructure plans. Brussels: European Environmental Agency: 1999.

EEA European Envirommental Agency. Corine land cover map, 1990 version. Brussel: European Environmental Agency: 2003.

EEA European Environmental Agency. Energy and environment in the European Union. Tracking progress towards integration. EEA Report No 8/2006. Copenhagen: European Environmental Agency; 2006a.

EEA European Environmental Agency. Transport and environment: facing a dilemma. TERM 2005: indicators tracking transport and environment in the European Union. EEA Report No 3/2006. Copenhagen: European Environmental Agency; 2006b.

ETT. EPYPSA. Desarrollo de un modelo de transporte interurbano de pasajeros y mercancías en España (CEDEX NEC 306053). Madrid: Boletín Oficial del Estado 28/ 07/2006; 2006.

FAO Soil maps, Roma: FAO; 2000

García-Montero LG, Mancebo S, Otero I, Casermeiro MA, Esplugas AP, Navarra M, et al. Screening de una Evaluación Ambiental Estatégica del Plan de Infraestructuras 2000-2007. In: Caselmeiro MA. Desdentado L, Diaz M, Espluga AP. García-Montero LG, Nelly DE, Puig J, Sobrini I, editors. Proceedings of III Congreso Nacional de Evaluación de Impacto Ambiental. Madrid: Asociación Española de Evaluación de Impacto Ambiental: 2005. p. 69-88.

García-Montero LG, Otero I. Mancebo Quintana S, Casermeiro MA. An elvirommental screening tool for assessment of land use plans covering large geographic areas. Environ Sti Policy 2008:11:285-93.

García-Montero LG, Mancebo Quitana S, Casermeiro MA, Otero I, Monzón A. A GIS raster model for assessing the elwirommental quality of Spain focused on SEA and infrastructure planning procedures (LATINO model). In: Rauch $S$, Mortison $G$, Monzón A, editors. Froceedings of 9th Highway and Urban Enviromment Symposium. Dordretch: Springer Netherlands; 2010. p. 31-8.

Geodäsie Eurogeographics EUREF. European Coordinate Reference System CRS; 2006. http://crs.bkg.bund.de/crs-eu.

Gontier M, Balfors B, Mortberg U. Biodiversity in environmental assessment - current practice and tools for prediction. Elwiron Impac Assess Rev 2006;26:268-86.

Goodwin PB. Empirical evidence on induced traffic: a review and synthesis. Transportation 1996:23:35-54.

Guirao B. El cálculo del trăfico inducido como herramienta el la planificación de infraestructuras de transporte. Aplicación a la puesta en servicio de las nuevas lineas de alta velocidad en España. PlD Thesis, E.TS.I Caminos. Madrid: Teclnical University of Madrid (UPM); 2000.

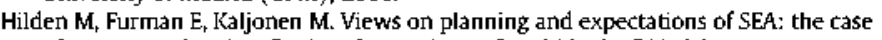
of transport planning. Environ Impac Assess Rev 2004;24:519-36.

Kessler JJ, Van Dorp M. Structural adjustment and the environment: the need for an analytical methodology. Ecol Econ 1998;27:267-81.

Lee DB. Demand elasticities for higlwway travel. HER5-ST v20, higlwway economic requirements system - state version technical report, FHWA-IF-02-060. Washington DC: Federal Higlwway Administration, Office of Asset Management; 2002 (Appendix B).

Litman T. Generated traffic and induced travel: implications for transport planning: 2004. http://www.vtpi.org/gentraf.pdf.

López, E. Assessment of transport infrastructure plans: a strategic approach integrating efficiency, cohesion and environmental aspects. PhD Thesis, E.T.S.I Caminos. Madrid: Technical University of Madrid (UPM); 2007.

Mancebo, S, García-Montero, LG, Casermeiro, MA, Otero, I, Esplugas, AP, Navarra, M. 2005. Modelo preliminar de la calidad natural de España 1:500.000. In: Casermeiro MA, Desdentado L, Díaz M, Espluga AP, García-Montero LG, Nelly DE, Puig J, Sobrini I, editors. Proceedings of III Congreso Nacional de Evaluación de Impacto Ambiental. Madrid: Asociación Espainola de Evaluación de Impacto Ambiental; 2005, 205-23.

Martínez-Falero JE, Gonzâlez S. Quantitative techniques in landscape planning. Boca Raton Florida: CRC Lewis Publishers; 1995.

Ministerio de Fomento. Análisis de los impactos territoriales producidos por los modos de transporte terrestres definidos en el Plan de Infraestructuras 2002-2007; conexión de la red española a las redes transeumopeas. Proyecto c03043002. Madrid: Ministerio de Fomento; 2003.

Ministerio de Fomento. PEIT Plan Estratégico de Infraestructuras y Transporte 20052020. Madrid: Ministerio de Folnento; 2004.

MMA Ministerio de Medio Ambiente. Guía para la Elaboración de Estudios del Medio Fisico: Contenido y Metodología. Madrid: Ministerio de Medio Ambiente; 2000. 
MMA Ministerio de Medio Ambiente. Mapa del paisaje de España. Madrid: Ministerio de Medio Ambiente; 2004.

Monzón A, Gutiérrez J, López E, Madrigal E, Gómez G. Infraestructuras de taansporte terrestre y su influencia en los niveles de accesibilidad de la Espana peninsular. Estud Constr Transp 2005;103:97-112.

Morrison SA, Winston $C$. An econometric analysis of the demand for intercity nansportation. Res Transp Econ 1985:2:213-37.

Noland RM, Lem LL. A review of the evidence for induced travel and changes in transportation and environmental policy in the US and the UK. Tansport Res-D 2002;7:1-26.

Norris WR, Famar DR. A method for the natural quality evaluation of Central Hardwood forests in the Upper Midwest, USA. Nat Areas J 2001:21:313-23.

Onate J. Pereira D. Suărez F, Rodríguez II, Cachón J. Evaluación Ambiental Estratégica: La Evaluación Ambiental de Políticas. Planes y Programas. Madrid: Mundi-Prensa; 2002.

otero I, Monzón A, García MB, Casermeiro MA, Canga JL. Impacto Ambiental de Carreteras: Evaluación y Restauración. Madrid: Asociación Española de la Camretera: 1999.

Otero Pastor I, Casermeiro MA. Ezquerra A. Esparcia P. Landscape evaluation: comparisol of evaluation methods in a region of Spain. J Erviron Manag 2007;85:204-14

Partidario MR. Elements of a SEA framework. Improving the added value of SEA Environ Impac Assess Rev 2000;20:647-63.

Polichtchouk Y. Geoinformation systems and regional environmental prediction. Safe Sci 1998; 30:63-70.

Ramos A. Planificación Física y Ecología: Modelos y Métodos. Madrid: E.M.ES.A; 1979

Saaty TL. The analytical hierarchy process. New York: MoGraw Hill; 1980.

Savelberg F, Vogelaar H. Determinants of a northern ligh-speed railway. Transporta tion 1987;14:97-111.

Schumaker NH, Emst T, White D, Baker J, Haggerty P. Projecting wildlife responses to alternative future landscapes in Oregon's Willamette Basin. Ecol Appl 2004:14:381-400.

Stead D. Transport intensity in Europe - indicators and trends. Transp Policy $2001 ; 8: 29-46$

Therivel $R$. Implementing the SEA directive: analysis of existing practice. Oxford Oxfordshire: Levett-Therivel Sustainability Consultants; 2002.

Tran LT O'Neill RV, Smith ER. A generalized distance measure for integrating multiple environmental assessment indicators. Land Ecol 2006;21:469-76.

Treweek JR. Hankard P. Roy DB. Arnold H. Thompson S. Scope for strategic ecological assessment of trunk-road developinent in England with respect to potential impacts on lowland heathland, the Dartford warbler (Sylvia undata) and the sand lizard (Lacerta agitis). J Environ Manag 1998;53:147-63.
UNFCCC. Kyoto Protocol to the United Nations Convention on Climate Change. Bonn: UNFCCC Secretariat; 1997.

Von Selit H. Requirements of a comprehensive strategic elvirommental assessment system. Landsc Urban Plan 1999;45:1-14.

Yao E. Morikawa T. A study of an integrated intercity travel demand model. Transport Res-A 2005:39:367-81.

Luis G. Garcia-Mentero, Dept, Forest Engineering, Teclnnical University of Madrid (UPM). B.Sc. in Biology. M.Sc. in Elwironmental Impact Assessment and Pl.D. in Plant Sciences. My research focuses on two areas: Environmental Impact Assessment models and Soils and Forest Ecology. I am currently a lecturer in Forestry Science at the Technical University of Madrid. I have participated in more than 25 research projects and I am the author or co-author of 67 papers or publications.

Elena López, TRANSyT, Technical University of Madrid (UPM). Civil Engineering Technician and Ph.D. in Transport Planning. My research focuses on two areas: Infrastructure and Accessibility Transport Plamning and Environmental Impact Assessment on these topics. I am currently a researcher in the Transport Research Centre TRANSyT (Technical University of Madrid UPM). I have participated in more than 4 research projects and I am the author or co-author of 6 papers or publications.

Andrés Monzón, TRANSyT, Technical University of Madrid (UPM). Civil Engineering Technician and Ph.D. My research focuses on two areas: Infrastructure and Accessibility Transport Planning and Environmental Impact Assessment on these topics. I am currently a Professor in the Transport Department of Technical University of Madrid (UPM) and the Director of the Transport Research Centre TRANSyT (UPM). 1 have participated in more than 43 research projects and I am the author or co-author of 138 papers or publications.

Isabel Otere Pastor, TRANSyT, Technical University of Madrid (UPM). Forestry Technician and Ph.D., I lecture on Topography at the Technical University of Madrid. Secretaly of the Transport Research Centre TRANSyT (UPM) at the Teclunical University of Madrid. I head the research line on Integrated Transport and Territory Plamning in TRANSyT, with the following main lines of investigation: EIA, GIS developinent and applications and territorial evaluation of transport systems. I am the author of almost 100 papers or publications. 